by Ricardo N. Alonso

National University of Salta, Argentina. Email: rnalonso@gmail.com

(Received: October 29, 2021; Revised accepted: October 29, 2021)

https://doi.org/10.18814/epiiugs/2021/021033

\title{
La Mujer en la Geología
}

\author{
Women in Geology from Argentina, Chile and Bolivia \\ Editors: Alina B. Guereschi, Roberto D. Martino and Victor A. Ramos
}

First Published: 2021

ISSN: 0328-2767

Published by Asociación Geológica Argentina https://geologica.org.ar/?s=La+Mujer+en+la+Geolog\%C3\%ADa

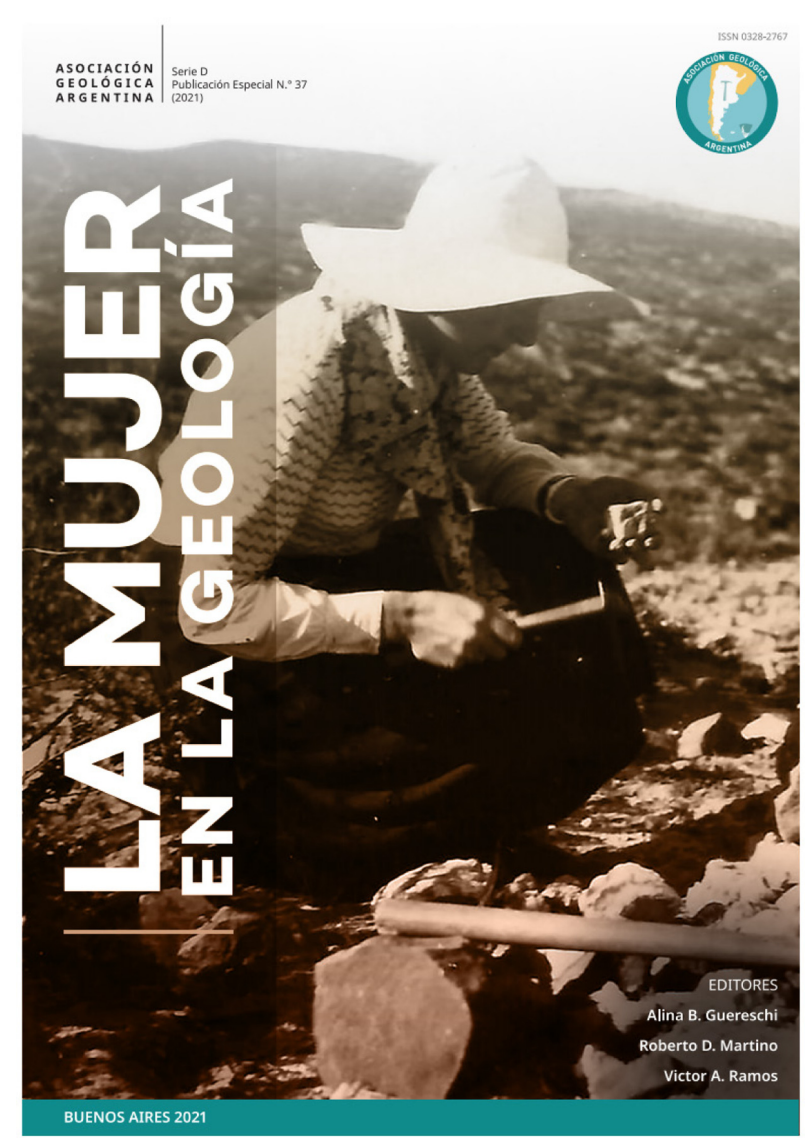

\section{Cover Photo: Paulina Mühlmann in the field in 1937}

This Special Publication by the Geological Association in Argentina (AGA) highlights the careers of a selection of pioneering woman geologists who excelled in teaching and in research, as well as in a variety of professional fields in Argentina and Chile. The collection of 17 research papers brings to light important figures within the South
American context by presenting biographies or reviews of their lives, illustrated by photographs and other documents that allow us to reconstruct the environment in which they trained and their struggle to advance in the field of Earth Sciences. The papers are in chronological order ranging from the early 1800's into the early decades of the $21^{\text {st }}$ century and are related to different geological institutions both in Argentina and Chile.

It is crucial to underline that these women, due to the constraints imposed by society of their time, were mostly employed to work on museum collections especially within the disciplines of Mineralogy and Petrography, as field work at that time was reserved exclusively for men. However, there were notable exceptions and through the stories of these women we can trace a progressive integration of women in Geology, although clearly there is still a need for equal rights and opportunities within areas such as education, public and private enterprises and within diverse disciplines of the science.

The opening story in the volume is about a pioneer of Seismology in Chile, Maria Graham (1785-1842). She published the results of her studies in 1824, being the first woman to do so in a leading British geological journal. She fought against ideas and hypotheses of the time, provoking a controversial discussion on the origin of earthquakes with the director of the Geological Society of London. An international debate was generated by those who agreed with Maria, who held modern ideas in times when science was written by men.

In the 19th century we learn that Doña Ascención Isasmendi de Dávalos (1817-1910), a widow with five children, was the first woman involved in the business of mining in Salta (Argentina). She was forced to make a living by producing wines and the mineral extraction of borates. Even if she was not a geologist, her life was marked, in part, by an activity questioned today by certain sectors of society: mining.

In the $20^{\text {th }}$ century we encounter Edelmira Mórtola (1894-1973), the first woman geologist to obtain a degree in Argentina at the University of Buenos Aires (UBA), who later became a professor of Mineralogy at that institution, where she established a Natural Science Museum that housed rock and mineral collections. She was considered an important consultant in national academic and public affairs. 
Edelmira was the first woman in 1956 to be promoted to full professor in the Exact and Natural Sciences School of the UBA, after decades of male predominance in the principal teaching positions.

The careers are reconstructed of the first five women geologists that graduated from the University of Buenos Aires between 1920 and 1935: Edelmira Mórtola (1894-1973, Jova Clara Yussen de Campana (1907?), Zulema Cristina Chiesa (1908-1987), Adela Magdalena Argentina Mangano (1908-?) and Paulina Mühlmann (1912-2009). These women worked in different fields of geology: university, oil industry, mining and high school education. Their positions were more related to museum rather than fieldwork, especially in Mineralogy and Petrography. The paper emphasizes that, of the first 10 graduates in geology, five were women, and shows the differences in opportunities available to women and men in the early twentieth century in Argentina, mainly in Buenos Aires.

María Casanova (1899-1947), an Italian chemist and petrographer, organizer of the first petrographic laboratory of the National Oil Company (YPF) in the late 1920s, made important contributions to the description of the stratigraphic column of the San Jorge Gulf Basin, the first oil producing basin of Argentina, contributing also to the geological knowledge throughout the country, together with her students. She was a professor at the Petroleum Institute of the University of Buenos Aires and took part in 1946 in the founding of the Argentine Geological Society.

An intriguing account is given of a little-known activity by the great sculptor Lola Mora (1866-1936) as an oil and mining businesswoman. Lola created beautiful sculptural works dedicated to myths and universal values in one of the most iconic rocks in geology, marble. Notably, in 1926, she conducted chemical and geological research on unconventional oil sources within the oil shales of the Cretaceous Yacoraite formation and she also explored the Argentine Puna looking for gold, copper, and sulphur.

Pierina Pasotti (1902-1996), pioneer geologist and geographer, had an academic career that spanned more than 60 years. She was the first emeritus professor appointed by the University of Rosario in 1969. Born in Argentina she studied in Italy, graduating from the University of Turin in 1927. She held various teaching positions in the national universities located in the region of Littoral and city of Rosario. Her work contributed, in greater depth, to knowledge on the neotectonics of the Argentine Pampas and in particular the province of Santa Fe.

The academic and family life of Josefa Vicenta Giambastiani de Peláez (1891-1974), relates the story of the first woman to be awarded a doctorate in Natural Sciences in 1931 from the National University of Córdoba, specializing in Geology and Mineralogy. An excellent petrographer and mineralogist, she was an exceptional secondary school teacher and was well known in the city of Córdoba and in the main cities of the province such as San Francisco and Río Cuarto. She wrote numerous school textbooks and stood out as an exemplary mother, having provided a university education to her five children during the difficult times of the Great Depression crisis that affected most countries in the world.

Perspectives on the lives of women graduates of the National University of La Plata in the early twentieth century, complement the biographies above on women graduated from the University of Buenos Aires in the same period. The roles of the first women geologists to graduate in 1932, Sarah Cortelezzi, and her sister Juana are highlighted. The latter held the first teaching position by a woman at the
National University of La Plata. Another graduate, María Magdalena Rádice, made important contributions to the description of the mineral rhodochrosite and became director of the Forensic Laboratory of the Police Force of the Province of Buenos Aires.

Paulina Mühlmann (1912-2009), with a doctorate in Natural Sciences, held the positions of head of laboratory, petrographer and field geologist. The latter role was remarkable for her time and was even documented as a record in her doctoral thesis completed in 1935. She was the first woman geologist to carry out this type of work at the University of Buenos Aires, which had been strictly reserved for her male colleagues. To mark this pivotal role in the history of geology her photo has been used as the cover of this publication.

In the second half of the $20^{\text {th }}$ century María Afazani de Juárez (1918-?), a petrologist and professor at two universities (Córdoba and Río Cuarto) was appointed petrographer at the Ministry of Mining of the Province of Cordoba. "Doctora Juarez", as she was called with much respect, is remembered fondly by her students of Petrology in the 1970s for her dynamic personality, profound knowledge of rocks and her didactic ability.

Hetty Bertoldi de Pomar (1924-2020), was a renowned expert in phytolytic studies both at national and global level. Born in Santa Fe and a graduate of the Universidad Nacional of Córdoba, she held positions at the Universidad Nacional del Litoral, in the public sphere of the Province of Santa Fe and in CONICET.

Milka Kronegold de Brodtkorb (1932-2019), a graduate from the University of Buenos Aires, specialized in Germany on mineralogical and metallogenetic subjects and is remarkable for her long scientific and teaching career, the excellent training of her students and her many contributions on research of mineral deposits reflected in publications at national and international levels. In recognition of her achievements, she was nominated Academic within the National Academy of Sciences of Córdoba, received numerous awards from the Geological Association of Argentina and the Strobel Award from the University of Buenos Aires.

The story of the pioneer women at the University of Chile, at the time of its establishment, in the 1950s to 1970s, highlights the contributions of Cecilia Verdejo (b., 1959, first qualified geologist), Sonia Mehech (b., 1959), Gloria Valenzuela (b., 1961, Engineering Applied Geology), Gloria Mancilla (b., 1963, Hydrogeology), María Cristina Muñoz Mellero (b., 1963), Patricia Narváez Dinamarca (b., 1966, Mining and Exploration) and Margaret Mercado (b., 1971, Regional Geology), who paved the way for others in the Earth Sciences within the national context of Chile.

Juana N. Rossi (b., 1940, is a petrologist with a strong interest in petrographic mineralogy using loose grain techniques and the development of knowledge about metasomatic rocks. Her trajectory began in Córdoba with the study of marbles and skarns in the quarries of Alta Gracia, she continued in Italy with the metamorphic rocks of the Adamello contact and ended her career at the Tucuman University. In this institution at the Natural Sciences School and Miguel Lillo Institute, she carried out numerous investigations and trained numerous students in the field of Mineralogy, Petrography and Geochemistry.

Margarita Toro (1947-2015), a daughter of Bolivian immigrants to Argentina, was a palaeontologist and a specialist in Palaeozoic fauna and also a social activist in the villas of the city of Salta. Kidnapped, imprisoned, tortured and forced to leave the country, she trained as a 
researcher and teacher at the Universidad Mayor of San Andrés in Bolivia, becoming one of the key figures in Bolivian Palaeontology.

Finally, the closing paper regards the experiences of woman geologists who started their professional careers between 1970 and 1990 in the oil industry and particularly in the YPF Argentinian Oil Company. The testimonies and personal experiences of Gladys Angelozzi, Graciela Covellone, Licia Manacorda, Viviana Meissinger, Angela Melli, Muriel Miller, María Luisa Rodríguez Schelotto and Silvia Zencich are presented. Current research highlights that equal rights and opportunities for women geologists in the oil and gas industry still have a long way to go.

Episodes does not have to share the same opinion as reviewers and we do not take responsibility for reviews and comments.

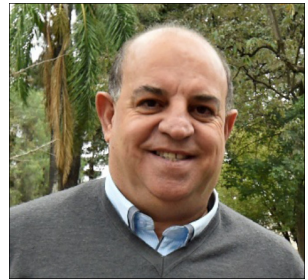

Ricardo N. Alonso (Born 1954, Salta, Argentina). Degree in Geology (1978) and Doctor in Geological Sciences (1986). Emeritus Professor in the National University of Salta (UNSa). Retired Scientist of the National Research Council of Argentina (Conicet) Fellow GSA and SEG. INHIGEO member for Argentina. Former State Secretary of Mining and Energy of Salta province (Argentina). Academic from Buenos Aires Academy of Science. Argentinian Prize of Geology. Medal of the Argentina Senate. 